International Journal of Instruction e-ISSN: 1308-1470 • www.e-iji.net

Article submission code: 20200127112741

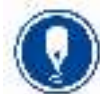

January $2021 \bullet$ Vol.14, No.1

p-ISSN: 1694-609X

pp. 963-982

Received: 27/01/2020

Revision: 13/08/2020
Accepted: 04/09/2020

OnlineFirst: 12/12/2020

\title{
Understanding and Applying Writing Strategies in Third Cycle of Primary School
}

Dušanka Popović

Dr., Faculty of Philology, University of Montenegro, Montenegro,

dusankap@ucg.ac.me

In the light of the fact that the activity of writing as a basic and generic educational ability is of paramount importance for lifelong learning, i.e. for life and work of each individual, and bearing in mind the notion that writing as a complex activity requires a whole corpus of knowledge and skills necessary for successful realization, we deemed it significant to explore whether third-cycle students from twelve primary schools Montenegro recognize and apply writing strategies to gain competence in this field of mother tongue and literature teaching. This paper presents the results of the research which examined the understanding and application of primary writing strategies, as well as the assessment of their significance in respect to oneself as a writer. The research focused on the creation of prose texts based on literary-artistic texts (novellas and short stories), i.e. a descriptive and narrative type of creative writing. Based on the results produced by the study, students recognize and apply the offered writing strategies to a greater or lesser extent, which is especially corroborated by the fact that they ranked each of them first in a certain percentage. Moreover, the results of the research indicate that a significant number of research participants assess themselves as a successful creator of a written text, naming the strategies that have particularly contributed to this, as well as those whose application should be enhanced.

Keywords: text, literacy, process approach, writing strategies, primary school

\section{INTRODUCTION}

Oral and written expression is a very extensive and particularly significant area of mother tongue and literature teaching, which incorporates all the knowledge and skills acquired in the teaching of this subject. Oral and written language production of students is a logical and natural continuation of the reception of artistic and non-artistic texts that students receive (listen and read) during both language and literature teaching.

A student's language product, whether spoken or written, comes as a result of work and learning in all fields of language and literary education. When speaking, students demonstrate the application of orthoepic and grammatical norms, i.e. the rules they have adopted during their studies - from proper pronunciation of phonemes to proper

Citation: Popović, D. (2021). Understanding and Applying Writing Strategies in Third Cycle of Primary School. International Journal of Instruction, 14(1), 963-982. https://doi.org/10.29333/iji.2021.14157a 
accentuation, diction and intonation. When writing, students display to which level they have adopted spelling and grammar rules, as well as knowledge of laws of producing a text appropriate to their age. Mindful of language, style and spelling of a written composition, a student strives to integrate them into valid statements and a complete text. That is why written compositions are the most comprehensive and all-embracing form of teaching, but also the greatest test of knowledge in the field of this subject (Nikolić, 2009).

It is through empowering students to produce a correct written text that their competence is significantly acquired when it comes to the first of eight key competences for lifelong learning (European Commission [EU Commission], 2018a) - the literacy competency: "Literacy is the ability to identify, understand, express, create, and interpret concepts, feelings, facts and opinions in both oral and written forms, using visual, sound/audio and digital materials across disciplines and contexts. It implies the ability to communicate and connect effectively with others, in an appropriate and creative way. Development of literacy forms the basis for further learning and further linguistic interaction. Depending on the context, literacy competence can be developed in the mother tongue, the language of schooling and/or the official language in a country or region" (European Commission, 2018a, 2). Gaining literacy competence also requires a competent teacher who understands that text creation is part of that competence, and that it is his or her obligation to further the understanding of writing process through personal experience and to improve his or her practice accordingly (Gains \& Graham, 2011).

Writing is a very complex and cognitively demanding activity, as well as one of the fundamental or generic educational abilities that are acquired throughout primary education and continually developed throughout the whole life (Nikčević-Milković, 2016).

Teaching students to write is one of the important learning outcomes in the Curriculum (2017) for language and literature teaching in primary school in Montenegro. Within that outcome, the process approach which encompasses the writing strategies whose application we analysed in the research was proposed, based on previous positive experiences of teachers and the research results on its implementation (Popović, 2018). Given the partial openness of the curriculum, the teachers have the opportunity to plan writing classes in accordance with the needs of students they teach and based on the circumstances in which they teach, which creates conditions for effective teaching of the strategies we examine, as well as their functional application.

\section{Theoretical Framework}

What actually is writing? Theorists define it in many ways, but its essence always remains the same - it is a creative act that requires a certain creative charge, and the ability to convey personal reflections, emotions and attitudes by means of written word to the audience. It is the way in which a writer shapes their idea to a level at which it can be successfully communicated to readers, while connecting with readers through a topic developed from and based on a original idea (Steele et al., 2004). Dyson and Freedman 
(2003) define writing as a developmental and flexible process influenced by a writer's abilities, the type of writing, and the conditions in which writing takes place.

Where the creative product comes from and what it takes to create it are questions that theorists and researchers in the field have disagreed with since ancient Greece. Namely, Plato considered poetry to be of divine origin and to emerge as an expression of inspiration - poems are divine work, and poets are interpreters of the gods who act in the inspiration of the soul. Aristotle, emphasizing technical solutions in one poetic work, highlighted the ability of individual talent and excluded the presence of divine inspiration in it. He believed that everything depended on the personal will, imagination and power of a poet to present events as vividly as possible or to reach as deeply as possible into the being of the character represented in their work. Plato and Aristotle are founders of two conflicting theories of creative writing that will be revisited in later literary periods, with new features and different formulations attributed to both these theories (Djordjić, 2014).

The analysis of literary works throughout history made it possible to describe the element the work is comprised of and to determine its genre (prose, poetry, drama) and form (poem, story, novel, novel ...) in accordance with the observed characteristics. It was particularly the literature theory that dealt with this, but other sciences (anthropology, linguistics, psychology, sociology, aesthetics, philosophy ...) made a contribution to shedding light on the mystery of the composing a literary creation, its uniqueness and the path that the creator followed. Furthermore, a great contribution to shedding light on the activities of creative writing was made by writers who decided to share the secret of creation with readers (e.g., Umbero Eco, Edgar Allan Poe and many others).

Finally, the research of creative process shows that a masterpiece requires a certain talent that often comes with subtle sensibility, inventiveness, fancy and imagination (Djordjić, 2014). Nonetheless, effort, learning, knowledge, skill, energy and perseverance are also vividly present factors in the creation of a good text or a masterpiece. The work can also be well-crafted, which confirms the fact that writing to a certain level can be learned and that it is possible to acquire a good enough basis in school for further work on developing a writing competency in accordance with each individual's life needs and intentions.

As part of language teaching, students read non-artistic texts of various types and produce texts modelled after those they have read. Non-artistic texts have a more rigid form, as well as style, (scientific, business, publicist, and administrative) that need to be known and that foreground the communicative function of language. Such texts usually serve as a means of communicating data about the outside world, human experience and knowledge, and are informative in nature. They have a set form, so it is relatively easy to teach students to meet the requirements of administrative and conventional communication, i.e. to write letters, greetings, thank-you notes, payment slips, fill in forms, but also write texts based on popular science articles. Knowledge of text structure is an important strategy that particularly affects the quality of this type of text (Englert et al., 1988). 
In literature classes, students create texts that emulate literary works. Literary text, distinct as it is, is marked by the existence of two associated relations integral to its comprehension - the relation to language and the relation to reality. Literary works carry the vital messages that exist and can only be comprehended because they have been conveyed in a particular way (Solar, 2012). Moreover, reading literary works contributes to the further development of students' imaginative abilities, along with the ability of analytical thinking, combinatorics and prediction, and at the same time, it introduces students to shaping different experiences in words (Grosman, 2010). Every writing task requires a certain amount of creativity, but creating a text modelled after a literary text, or writing fiction, opens up much greater possibilities for being unique. Wideness and freedom of choice, polistylistic and aesthetic orientation of this style puts it in contrast with all other functional styles. It has the dominant role in functional stylistic decomposition and it mostly represents lexical and grammatical potential of language, and is characterized by a large and diverse expression. Type of thinking underlying the literary style could be called esthetical transformation of the reality, that is, the transformation of observations and perceptions through subjective experience and shaping (Tošović, 2002).

Successful oral and written forms, with all its particularities, are important for further development, progress, life and future work of the student. Both activities incorporate the knowledge as well as many a skill acquired through language and literature teaching, which are expressed, functionally applied, developed and enhanced in applying different creative writing strategies such as: finding and selecting material relevant to the topic and its functional structuring, knowledge of the text composition and knowing the rules of its composing; having a skill to form paragraphs and contextualize them in to whole style as a whole, having and choosing appropriate vocabulary and possessing knowledge of different forms of expression (description, narration, dialogue, monologue ...), i.e. style as a whole, as well as the application of grammatical principles, i.e. spelling rules when it comes to a written text. Even though both activities require hard work to achieve satisfactory results, teachers point out that it is the written language that poses a bigger problem for students. Namely, written language depends more upon the grammatical norm and its syntactic structure is more complex than the structure of the spoken language (Rosandić, 2002). Therefore, it is understandable that so far methodologists have dealt with written student production rather than oral.

The latest methodics concepts of teaching writing rely on the results of text linguistics, and lately it is the stylistic component in the development of the culture of writing that has begun to assert itself - i.e. the viewpoint that the culture of writing is acquired by getting to know and use the expressive possibilities of the standard language at all its levels (Rosandić, 2002).

An analysis of existing approaches to teaching writing (presentation, interaction, instructional, free and process) shows that the process approach (as well as the interaction approach, but in this paper we will focus solely on the process approach) provides the most opportunities to develop the strategies necessary to master writing competency as a whole. The process approach is based on the principle of 
individualization of the teaching process, which means that little and young writers choose a topic to write about led by personal interests, knowledge and preferences (as well as the audience for which they write). The second postulate of this approach is that students have as much time at their disposal for writing as they need. This approach consists of several stages all of which aim at developing appropriate strategies: selecting a topic and/or its title, collecting material, making a text plan, selecting and structuring material, composing the first draft of the text, consulting a teacher and classmates, composing a second draft of the text, editing and proofreading and publication of works. During this process, students have continuous teacher support and feedback - they discuss the composition of the assignment, the relevance of the material, the place and role of the characters in the story, the event and the way it is developed, the logical layout of the details, the passage outlines, the appropriateness of certain forms of expression (descriptive, narrative, monologue, dialogue...) and finally the grammatical, spelling and graphic organization of the text. This means that primary school students need to master primary and, at least to some extent, secondary writing strategies. According to Wright and Rosenberg (1993) the primary writing strategies are: defining the topic, audience and purpose of writing, making a text plan, collecting material, and preparing the first draft, discussing the key idea of a text, etc., while secondary strategies are: anticipating criticism, asking questions, figurative language, historical data, diagrams and letters, literature, etc.

Murray (1985), who was among the first to describe this approach as way of teaching writing, warns that the processes associated with the act of writing vary with each new writing and that one should keep in mind the personality of each writer, their cognitive style, and their experience for teaching to be effective and successful.

The research of the existing approaches to teaching writing in Montenegrin primary schools indicates that teachers still give preference to the presentation approach as traditional and proven, but at the same time, the data show that the process and interaction approach as innovative methods in the explored area, are positioned immediately after the presentation approach. This testifies to the positive changes in the field of writing and the transition from product-oriented writing to process-oriented writing (Popović, 2019). Therefore, the significance of this research lies in determining the attitude of students towards the offered writing strategies and assessing how the students perceive their significance in respect to themselves. The results should contribute to a greater understanding of the utmost importance of being familiar with these strategies and their more intensive application in the process of teaching creative writing to primary school students.

\section{Defining the Problem}

Research and analysis of teaching oral and written expression in schools in Montenegro show that students mostly create texts during one school class (45 minutes), writing on a topic chosen by a teacher or less frequently on a subject of their own choosing. The research also indicates that the independent creation of text is, in general, introduced through a presentation procedure (a teacher explains the type of text to be written, its style properties, structure and form of expression, then evaluates and corrects the text), 
and that students generally do not understand the function and importance of making a text plan. Therefore, the accomplishments in the field of creative literacy are usually repeated according to the principle: two or three students in the class write a stylistically linguistically sound text in terms of its composition and content; the same group of students writes in order to address the topic and meet the requirements set by a teacher without much zeal and creativity, while a number of students produce texts that, in form, content and style, do not meet the age criteria. Often one or even more students in a class do not write at all. Such situation leads to conclusion that there is a lack of continuous teaching of writing skill, and that the teaching of written expression relies mostly on what students inherently have, i.e. it rests on students' talent. Furthermore, apart from creating a text independently as a form of individual work, nothing else in the process is individualized, despite the fact that creation of text, artistic or non-artistic, is a distinctly individual act (Popović, 2013; (Bureau for Education Services [BES], Examination Center of Monetnegro [ECM], 2012; Examination Center of Monetnegro [ECM], 2015).

Numerous studies from many countries report positive effects on pupils' writings when the process approach to writing was a part of the writing instruction (e.g., Graham, McKeown, Kiuhara \& Harris, 2012; Graham, \& Perin, 2007; Graham \& Sandmel, 2011). Applying the process approach to writing (Emig, 1967, 1971; Flower \& Hayes, 1981; Graves, 1983, 1994; Hayes \& Flower, 1980, 1986; Murray, 1968, 1972) in a number of schools in Montenegro through innovative educational programs has proven to be effective, as it allows for an individual approach that teaching writing lacks and its application provides teaching primary writing strategies (Popović, Novović, 2016; Popović, 2019). Moreover, the possibility of choosing a topic and writing over a period of more than one school hour can solve the problem the research has highlighted as the most vital in the writing process (Popović \& Novović, 2016). Applying this approach and monitoring the teaching of writing in schools, as well as the output i.e. student texts have shown that students taught by using this approach possess knowledge and skills in the field of text creation and are more eager to engage in this activity. That is why we decided to examine students' attitudes toward the particular writing strategies that they adopt as part of the process approach. The research focused on the creation of prose texts based on literary-artistic texts (novellas and short stories), i.e. a descriptive and narrative type of creative writing.

The research question, therefore, was: do the students of third cycle of primary school know, understand and apply the writing strategies offered within the process approach necessary for successful writing, and do these strategies contribute to students' competence in this field?

The above stated research question set the research objective: to determine whether the students of third cycle of primary school know, understand, and apply the writing strategies offered within the process approach, and how they assess their significance in respect to themselves.

The research should contribute to understanding the importance of teaching students the writing strategies adopted through the process approach, and their more extensive 
application in teaching in order to enhance students' competence and increase the intrinsic motivation for writing in primary school.

\section{METHOD}

The undertaken research, according to the method of data collection, belongs to the group of quantitative research based on the collection of numerical data, whose analysis and establishment of cause and effect relationships and relationships between quantitative data obtained by statistical processing have led to certain results and, accordingly, appropriate conclusions. Upon defining the problem in the form of research questions and determining the research objective, we have put forward a hypothesis, and through the selected technique and appropriate instruments, collected the necessary data on a selected sample. Based on the way data are analyzed and interpreted, this research can be categorized as descriptive and causal-comparative, as we seek to systematically and factually describe and define certain specific characteristics of the observed objects or phenomena and examine the influence of the independent on the dependent variable.

\section{Research Hypothesis}

In line with the aforementioned research objective and research questions, we have put forward the following hypothesis: the students of third cycle recognize, understand, and apply writing strategies taught by teachers as part of the process approach at school, and perceive that the implementation of these strategies contributes to enhancing their writing creativity.

\section{Research Sample}

The basic set (broadly defined) comprised all third-cycle students (seventh, eighth and ninth graders) of primary school in Montenegro. By means of sample method, we extracted from the basic set the research set as a representative research sample. A representative sample consists of 154 respondents, third cycle students from 12 primary schools, from all three regions in Montenegro: southern, central and northern. We chose the third cycle students because we believe that at that age, they can identify and rank strategies that helped them create a good text in terms of language, style and content. The interviewed students were taught writing through the process approach within the project "How to Help Students Successfully Create Oral and Written, Artistic and Nonartistic texts" (Bureau for Education Services, 2013).

Table 1

The basic set of research

\begin{tabular}{llllllllllll}
\hline City & Region & \multicolumn{2}{l}{$\begin{array}{l}\text { Number of } \\
\text { schools }\end{array}$} & \multicolumn{2}{l}{$\begin{array}{l}\text { Grade and number } \\
\text { of pupils }\end{array}$} & M & F & \multicolumn{2}{c}{ Achievement } \\
& & & VII & VIII & IX & & & E & VG & G & S \\
\hline Podgorica & Central & 4 & 21 & 21 & 22 & 30 & 34 & 16 & 16 & 16 & 16 \\
\hline Nikšić & Central & 2 & 10 & 10 & 10 & 15 & 15 & 8 & 8 & 7 & 7 \\
\hline Bijelo Polje & Northern & 3 & 10 & 10 & 10 & 15 & 15 & 8 & 8 & 7 & 7 \\
\hline Bar & Southern & 3 & 10 & 10 & 10 & 14 & 16 & 8 & 8 & 7 & 7 \\
\hline & TOTAL: & 12 & 51 & 51 & 52 & 74 & 80 & 40 & 40 & 37 & 37 \\
\hline & & & 154 & & & & & 154 & & \\
\hline
\end{tabular}




\section{Technique, Instrument and Research Variables}

In order to obtain data relevant to the goal of our research, we used a survey technique and we used a survey questionnaire composed of closed, semi-structured and thematically organized questions as an instrument. The questionnaire comprised ten questions, eight of which were closed-ended (four questions with the possibility of choosing one or more answers, two questions of alternative choice and two questions in the form of a scale), as well as two combined questions (one multiple choice question and one in the form of a scale rank question with the possibility of explaining and adding some more categories which makes this question partly open).

The questions were focused on students' experiences in the process of independent creation of a written text within the process approach and their relationship to the different stages of its creation (from preparation for writing to the final version of the text). The questionnaire was delivered to the respondents in writing, with instructions for its completion. At the beginning of the questionnaire, in its general part, the respondents provided information about the school and class they attend, followed by information on gender and accomplishments in the field of Mother Tongue at the end of the first semester. These data were mainly used to describe the research sample and indicate its representativeness.

For the purpose of this paper, we used the answers provided to two questions - the first question was given in the form of a rank scale (the categories offered were to be ranked according to students' personal attitude to each of them), while the second question was in form of multiple choice answers and students had to choose one. Within the first question, the respondents were asked to rank seven key activities, i.e. strategies used in the process of writing a text by marking the one that they considered the most important for their own creation with number 1 , and the one they as individuals deemed to be the least important with number 7. In doing so, they could skip/ignore the one that they do not deem important, do not use it or are not familiar with. The strategies offered relate to formulating topic and its title, collecting material, planning and drafting a text, creating sentences and grouping them into paragraphs, as well as spelling and grammatical accuracy of the text. The question was aimed at determining whether the respondents know and apply the writing strategies offered and how they assess them. In the second question, the respondents were asked to assess their own competence in this area by selecting one of the four options given. The question was aimed at determining the respondents' attitude towards their own writing skills. In both cases, the respondents had the opportunity to clarify further options they ranked or circled in the posed question i.e. the opportunity to explain the choice of the first-ranked strategy in writing, as well as the assessment of their own competence to write creatively.

A preliminary survey conducted on a small sample of respondents (20) aimed to test the validity and reliability of the instrument used. Listed metric characteristics were established by means of an assessment by three associate researchers through a comparative analysis of the issues and phenomenon under examination (validity), as well as by determining the degree of equilibrium (Pearson's Correlation Coefficient) between the results the respondents achieved in the first and the second application of 
instruments (reliability) (Bandjur \& Potkonjak, 1999; Halmi, 2013). This degree was determined to be $0.8(\mathrm{p}=0.0025)$. Afterwards, certain corrections were made to some items in order to improve the original version of the research instrument.

A dependent variable of this research is the recognition, understanding and application of different writing strategies offered within the process approach in third cycle of primary school. Independent variable is the continuous teaching of students to certain strategies, knowledge and skills needed for writing through the process approach to teaching writing.

A limitation of the research may be giving desirable answers by some of the respondents due to their wish to show good knowledge and skill in this field. We tried to prevent this situation by providing detailed information on the way the research was undertaken, the anonymity of the data, as well as the purpose for which the obtained results would be used.

By analysing the answers from the questionnaire, we obtained quantitative data, whereas the explanations of the choice of the first-ranked strategy and the assessment of students' own success in text creation provided us with a form of qualitative indicators as regards the explored issues. The program for graph-analytical and tabular processing Excel was used in the statistical processing of data. The aforementioned explanations, thematically linked to quantitative data, were presented as illustrations, explanations or confirmations of data obtained by quantitative analysis. Statistical processing of data and their analysis enabled drawing relevant conclusions regarding the research question and the goal of this research.

\section{FINDINS AND DISCUSSION}

Figure 1 demonstrates the distribution of percentages per stated categories as the firstranked with regards to their significance and functionality per each individual student. All respondents distributed the offered strategies on a scale rank from 1 to 7 in accordance with the instructions, while quite a small number of them used the opportunity to provide their comments or add a new activity. However, the comments provided are rather interesting and do we will quote some of them.

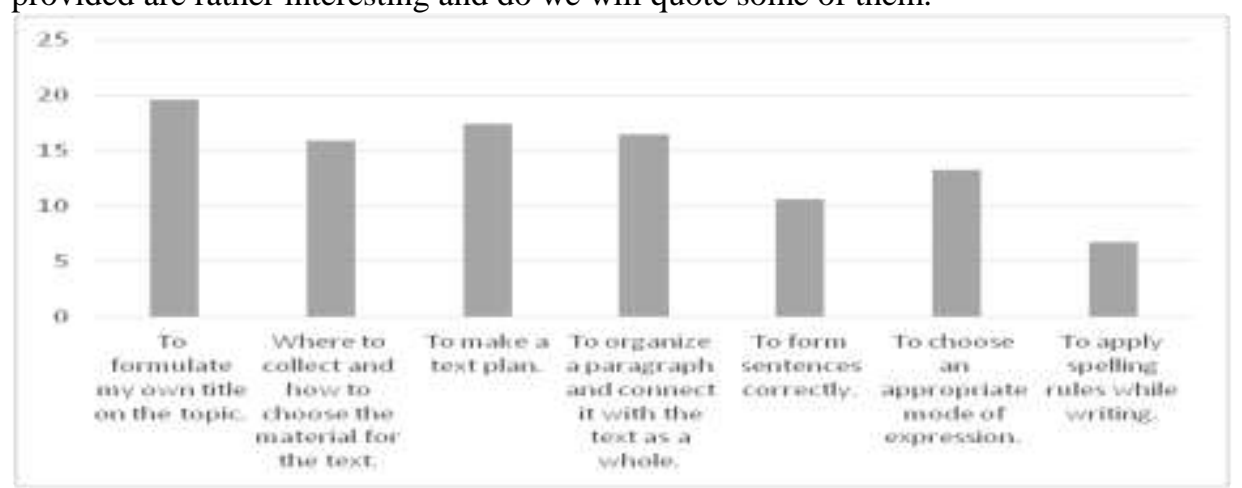

Figure 1

Distribution of percentages per offered strategies as the first-ranked 
The formulation of one's own title related to an assigned topic is ranked first by the students, having the highest percentage $(19.16 \%)$. When we consider the manner in which writers create, which is the strongest motivation for written linguistic production, it is clear that what is carried within oneself most intensively initiates creative energy: personal perceptions, emotions and reflections, as well as available material in terms of familiarity with and knowledge of the topic, make such attitude of students fully clear. Considering the fact that the corpus of the surveyed students had an opportunity tom choose the title with regards to previously offered topic or both the topic and the title, it is evident that they experientially emphasize this option, particularly when compared to previously undertaken research in which students, who did not have an opportunity to choose topic, emphasized this as the problem - even $33.78 \%$ students state that the topics are related to something beyond their interest, while $27.80 \%$ mention as particular difficulty the fact that they are not able to choose the topic or its title (Popovic \& Novović, 2016). A writer has to be familiar with the topic so as to formulate and express the ideas which they want to communicate to the readers by means of their text.

The selection of one's own title on the offered topic is one of the ways of individualization of a teaching process - by choosing the topic which may be interesting to students, a teacher opens up an opportunity for students to create their own title with regards to their personal experience and interest, thus achieving two goals: guiding students of an early age to firmly defend their decisions and leaving sufficient possibilities for choice and expression of personal and intimate details. "Thus, the practice has shown that the choice of topic and its title by each individual in the class is the most important step in not only starting and continuing the writing, but in overall quality of children's creativity in this field" (Popović \& Novović, 2016, 1248).

The strategy of finding material and content for text and its selection are ranked fourth by the students, thus following the choice of the topic, development of the plan and organization of paragraphs, with the percentage of $15.79 \%$. Since the phase of the socalled documentation "is actually one of a kind research of the topic" (Visinko, 2010, 10) sufficient attention has always been dedicated to it within teaching - whether by direct observing of natural and social objects, through imagination, through evoking memories and creating new units based on them or which were achieved indirectly (by reading adequate literature, observing or listening to artworks, and the like) or by combination of both sources, will depend on the topic and its title. The next and very significant step requires the students to analyse collected material so as to choose only necessary and significant details, the ones clearly demonstrated by the viewpoint as the limitation of the topic. We also emphasize here that through the process of writing, students develop important dimension of literacy competence, as they practice how to find, differ and use information which "also includes the abilities to distinguish and use different types of sources, to search for, collect and process information, to use aids, and to formulate and express one's oral and written arguments in a convincing way appropriate to the context" (European Commission [EU Commission] 2018a, 2).

We would like to emphasize the following observations of students with regards to marking this phase as the most significant one. 
"When I write in this way, I have time for everything, especially to find the content for the text. I have learnt where and how to find it. It is important to me, because I have something to write about, and frequently to learn something new ". ( $7^{\text {th }}$ grade)

"I rank the collection of material first, since I write down everything that comes to my mind that is related to the topic. Later, I add new content I have found and I delete redundant information. At the end, the plan of writing becomes clear which makes me more confident, and my works are evaluated by a good mark both by my teachers and by my classmates. Now, I love writing more than I used to ". ( $8^{\text {th }}$ grade $)$

"I like to collect material because then I discover and read interesting books, texts and other things related to the topic I write about. When I have sufficient content, I can select what I need for the title I have chosen. I think that is the reason why my essays are good." ( $9^{\text {th }}$ grade $)$

It is clear that the respondents from all three grades recognize the importance of this strategy for the creation of an interesting, meaningful and well-structured text, logically connecting it with the development of its plan. In addition to this, they emphasize what they have learnt and what they could learn by the application of this strategy, pointing out that the skills and knowledge acquired within this process have made them become more confident in the area of writing, inclined to writing and also that their texts are better now.

The selection of the collected material is most efficiently implemented by its synthesis in the text plan, so it is not a surprise why the students positioned this strategy immediately after the choice of the topic, with $17.38 \%$. Through the implementation of the process approach in teaching writing, particular attention is actually dedicated to the creation of the text plan as the result of a reflection on possible distribution of the collected material and its selection with regards to the focus of the topic and key idea of the text.

High ranking of making a text plan which defines its original composition and structures the collected content confirms the fact that the respondents have recognized and understood the significance of this strategy through its application. This complex activity encourages cognitive abilities of students placing the tasks of analysis and synthesis before them, as well as the separation of important from unimportant details, classification of facts and other material and hierarchical arrangement of terms with regards to their superordination and subordination. Teaching to write should concentrate more on teaching cognitive processes that support the writing activities such as planning and arranging (Gagnon \& Ziarko, 2012).

We would like to mention several observations of students who marked this strategy as the most important one:

"The plan has helped me not to meander off topic and it guided me. Now I find writing a satisfaction, not an obligation ". $\left(7^{\text {th }}\right.$ grade $)$ 
"When I make and use a text plan I cannot go off-topic too much. When I did not use it, I used to write too long boring essays. The plan helps me to make my text not boring, but interesting and with a lot of descriptions “. ( 8 th grade)

"I did not like writing a text plan and I thought that I wrote well even without a plan. Now I see that, owing to planning, I write better, I know exactly what I want and where I will write it. My assignments are nicer “. $\left(9^{\text {th }}\right.$ grade $)$

Students recognize a text plan as a guiding factor not allowing them to ramble in writing by putting, perhaps interesting details, but less relevant for the topic. The plan also helps them understand what exactly they want to write and where to do it or how to structure the collected material. All three respondents, due to the development of a text plan, emphasize their pleasant emotion in relation to the activity of writing and personal progress: writing is not an obligation any more, but satisfaction; my text is interesting now; my assignments are nicer...

The strategy of knowing how to organize paragraphs and their linking into the text unit is ranked first by $16.5 \%$ respondents. The strategies of the development of a text plan and selection and structuring of collected material are closely connected to this activity, and it is not by accident that students rank them first in approximate percentages. Defining text units via captions during the development of the plan provides the first guidelines for where to start and end one paragraph, or how many of them will be in certain part of its composition structure. The text is a single unit whose components are linked in certain order (links between text elements, grammatical and lexical devices uniting the sentences/expressions into the text) by which one of the seven principles of textuality is achieved - coherence principle (De Beaugrande \& Dressler, 1981). Readers presume the fact about the completeness of a paragraph, primarily owing to its graphical separation. They are visually prepared for searching and discovering the main idea written about in the paragraph, as well as its greater or smaller complexity. Based on such image, they create their expectations, identify different aspects and relationships with the main idea, as well as the level of its development.

To define the beginning and the end of a paragraph as a reflection and logical unit of sub-sentence status is not easy for primary school students. As a linked range of sentences which develop one and only idea, it is also the part of the text unit which with its other parts have to be meaningfully and firmly connected. In order to appropriately develop key idea of the text, it is necessary to additionally support it by the idea of each individual paragraph and this contributes to its illustration, argumentation and proving. In the teaching process, students will understand that the length of the paragraph depends on the importance of the idea, elaborated within it, for the text as a unit - an important idea will certainly get more space in the text created by the student. In organizing paragraphs, the following principle should be adhered to: "the paragraph is an essential unit of thought in writing". The paragraph should be unified, with all its sentences relevant to the main point (Strunk \& White, 2003).

The skill of organizing paragraphs is learned by analysing paragraphs taken out from the texts of distinguished authors - by identifying the key idea of the paragraph, and then 
those secondary ideas which additionally explain the main idea. It is also learned through analysing paragraphs in students' own assignments and the assignments of their peers, by identifying certain strengths and shortcomings in their structure.

We would like to single out the following students' observations in relation to denoting this phase as the most significant one:

„Previously, I was not certain how many paragraphs there were in the body, because it was easy for the introduction and conclusion. I think that now I do this well, because I know how to define what is the most important part of the paragraph and, then, what supports or explains the main idea. I deem that my written essays are better due to this. Now I feel more certain and I like writing “. ( $7^{\text {th }}$ grade)

„It is interesting for me how a paragraph is created and I use this when I write ". ( $8^{\text {th }}$ grade)

„I think that paragraphs are important, because they show one whole in a text. When they are well defined, the text is somehow clearer and easier to read and, hence, I try to determine them in well. I notice this also when I read somebody else's text “. ( $9^{\text {th }}$ grade)

It is clear that students who have undergone a continuous work on the comprehension of the essence of a paragraph and its function within a text, recognize the significance of this activity for the success of their own writing.

The correct formulation of a sentence as the first-ranked strategy appears in the percentage of 10,66 , which means that the students recognize this activity as the significant one, according to our assumptions, in line with their personal needs. In the process of creative writing, cognitively powerful ideas that an author wishes to convey to readers, must be translated into a text of an equal quality and this process relies on the cognition of adequate words, types of sentences and structure of a paragraph (Jay, 2003). Although the tested age group is expected to mainly possess the skills and knowledge regarding the creation of a clear sentence as a completed thought in relation with the problematics that the text elaborates on, the exercises dedicated to the formulation of a good sentence need remain the part of language and literature teaching until the end of primary school, and even later. It is a well-known fact that many adult and educated people are not so good in "putting their thoughts down on paper", i.e. their reformulation into a written language, especially when writing skill is not practiced daily or, at least, frequently.

Astuteness demonstrated in the selection of an appropriate manner of expression is emphasized by the students in the percentage of 13,28. Recognition, comprehension and application of various forms of expression is mainly envisaged by the curriculum for a certain grade and, to that end, teachers set as a task a topic in whose elaboration one of them is dominant: description, narration, dialogue or monologue, therefore, the one which is necessary for the expression of the prepared material and the essence of the idea that the writer wishes to convey to the readers. The other forms appear as a supplement, which complements the comprehensive experience of a written form. 
Both methodologists and teachers have always assigned particular importance to the selection of the appropriate form of expression as a writing component. In order for a written essay to be a success, the collected material and the idea intended to be conveyed to the reader must be shaped through an adequate linguistic expression whether this will be mainly narration, description, dialogue or monologue, depends upon the nature of the topic, on the idea intended to be conveyed, as well as on the gathered material. In any case, in order to produce a good written essay, students need to be familiar with all forms of expression, because they will most probably combine them in the course of writing, while one of them will be dominant. It is known that primary school students choose talking and narration more eagerly in relation to descriptions, "in particular, if we observe narration and description in contrast, it becomes clear that a student, and a human being in general, identifies more easily with moving, both the external and internal one, than with stopping in the middle of the movement for the purpose of observation" (Visinko, 2010, 41). The authors of the curriculum and teachers certainly take care about the adequacy of the forms of expression for the age of a student and, thus, the very selection of a wider topic that a teacher offers, provides the first guidelines about the form of expression which is necessary to be applied in the future work.

We would like to single out the following students' observations in relation to denoting this phase as the most significant one:

„I like describing and it is important for me to know how to do it well. When we have more time for writing, then we do everything better, which includes descriptions, as well"،. ( $7^{\text {th }}$ grade $)$

„The most significant thing for me is to narrate and describe the topic that I talk about in a nice manner. You should know when you should describe, when you should narrate and at which point the dialogues of the characters are important. It is good when we have enough time for this ". $\left(8^{\text {th }}\right.$ grade $)$

The comments by the students merely confirm what has been previously stated: the time is needed both for describing and narrating and they emphasize, as particularly important, the fact that they have more time than usually in the process approach. However, it is important to know which form is to be applied and when, which demonstrates that they recognize and appreciate the knowledge that they gain in order to write in a good and correct manner.

The successful application of orthographic rules is highly ranked by a low percentage of students, only $6,75 \%$ of them, most probably due to the fact that such knowledge and skills are implied when it comes to the tested age group. In the process approach, in the scope of which the students have the possibility of proofreading and editing the last version of their paper, with the utilization of the appropriate manuals (normative guides, vocabularies, language textbooks ...), the orthographic correctness of the task is, by the very nature of things, attainable. Writing an advanced version, i.e. the editing of one's own text directs students toward the utilization of the appropriate manuals, normative guides and vocabularies and, thus, the students, being trained for the successful written 
communication, continuously enrich their vocabulary and apply grammatical and orthographic rules, improving the functional grammar and the language functions in general (European Commission [EU Commission], 2018a). Simultaneously, they learn how to use the mentioned manuals from the very beginning of their school education.

Based on the results obtained regarding the first question and their analysis, it is clear that the respondents recognize and apply all offered strategies and techniques of writing, giving them priority, i.e. determining their significance in relation to their own needs. In this manner, they fortify the knowledge and skills, which are necessary for the writing activity and reaffirm the attitudes that contribute to the improvement of the written creation.

The second question which we posed to the respondents was to assess themselves as writers - the extent to which they are successful in this activity, as well as to account for their opinion. The attitudes of the students regarding writing, self-efficacy, and the connections between writing and success are important issues for the teacher (Hall \& Axelrod, 2014).

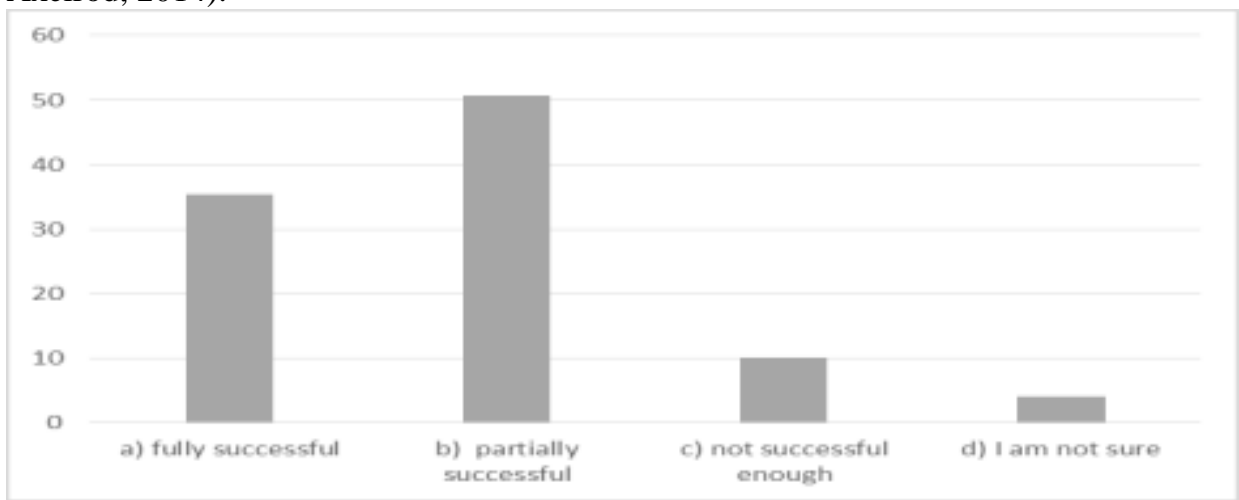

Figure 2

Overview of percentages in relation to three levels and the „I am not sure“option of the assessment of one's own successfulness in the creation of a text.

The majority of students $(50,67 \%)$ consider themselves partially successful in the creation of written texts, $35,3 \%$ of students consider themselves completely successful, while $10 \%$ of the respondents consider that they are insufficiently successful in this field. Only $4 \%$ of the respondents are not certain, i.e. they cannot assess themselves regarding this activity. When it comes to the self-assessment in relation to the being successful in writing, judging by the proportion of percentages, the students mostly feel quite sure about themselves regarding this teaching subject. Although a limitation may lie in the wish to be successful and, thus, unrealistic picture about oneself, the mentioned self-assessment of the students may also be interpreted as their positive attitude toward writing activity and the manner of teaching applied at school. There are studies finding that lessons using process writing decreased students' negative views about writing (Yayl1, 2009, in Bayat, 2014). 
A high number of students who assess that they are either partially or completely successful voiced their opinion, whereas a lower number of those who selected the third or the fourth category ventured theirs. We would like to quote several explanations stated by the students regarding this issue:

I am not certain: "I do not know how to assess myself, but I like the way we do this at school. We have more time, I can choose a title, collect the material, distribute the material in an adequate manner, correct mistakes. My teacher says that my writing is good". ( $8^{\text {th }}$ grade)

I am not sufficiently successful: "I think that I write better since we have been able to select a topic and since we have had more time to do this, but in my opinion I am still not successful enough". ( $7^{\text {th }}$ grade)

I am partially successful: „I think that I know how to select the material and to distribute it in an appropriate manner, I also know how to make a plan. I am always afraid whether my sentence is good, whether I have described the characters sufficiently. I am also not certain whether my story is long enough “. $\left(8^{\text {th }}\right.$ grade); „The title that I choose and the point of view, as well as the text plan, help me not to write about unimportant things and not to meander off-topic. Sometimes, it is hard for me to come up with a conclusion. I think that I could work on improving my style. I do not always like the way I do this ". $\left(9^{\text {th }}\right.$ grade)

I am successful: „I like to write and write, even when I am not at school. I often read my essays in the classroom and my teacher always commends my work. I have learnt how to collect the material, make a plan, what a good paragraph looks like ... I particularly like the fact that I can choose my title. I like writing descriptions. I do not make grammatical mistakes. I think I am successful because of all of this “. ( $8^{\text {th }}$ grade); „I think I am successful, because I use the plan to distribute the collected material in a good manner, which is the reason why the composition of my essay is good. It is significant for me that I can choose a title within a broader topic offered by the teacher, because then I am able to write about the subject which interests me most and that I know a lot about. It is also convenient for me that I have the time to do this well and that I am able to correct mistakes ". $\left(9^{\text {th }}\right.$ grade $)$

The percentage of those who do not dare to assess themselves, as well as those who deem themselves not successful enough is low. However, they also emphasize a positive attitude toward the strategies that are applied in the course of writing, noticing that some of these strategies help them be better in writing. The respondents who assess themselves as partially successful precisely state the strategies they have acquired, but also quote the particularities which still pose them difficulties. The students who assess themselves as successful point out almost all strategies which we have examined as something they are skillful at and what they do well and which finally results in a successful written essay.

The fact that even 87,33 of the total number of respondents feel quite certain in the area of written creative work and that they link such an attitude to acquiring of the writing strategies which they gain in the scope of the process approach to teaching of writing at 
school, is one more confirmation that the respondents know, understand and apply them in accordance with their own capabilities. They also assign priority to them, governed by their own needs, reinforcing those skills and knowledge which they have, in the course of writing, assessed as their shortcomings or which the teacher indicated to them as the ones to work on. In any case, individual process of writing during which the students are granted certain freedom in several of its segments opens the possibility of in-depth application of the offered writing strategies while students, assessing the efficiency of each of them for their own writing, allocate the appropriate space and time in their creative impetus. "In teaching to write adopting process based approaches and applications, directing to activity based paradigmatic lessons within teacher-student and student-student interaction and performing more activities regarding writing strategies will be effective for producing texts both in artistic and scientific platform concerning the writing skills of the students" (Sezgin, 2018, 69).

\section{CONCLUSIONS}

In accordance with the previously presented problem of research and its objective, as well as the hypothesis which originated from it, we may state that the obtained results demonstrate that:

- the students of third cycle recognize, understand and apply the writing strategies (precise and clear title, utilization of different sources of information, structuring of the collected material, the manner of its presentation...), taught by their teachers as partof the process approach at school - from the selection of a topic and its title to linguistic and orthographic correctness of the task

- $\quad$ all the offered strategies are deemed important by students, but choosing a topic and making a text plan are ranked first by the highest percent of them, which indicates the particular importance of applying these strategies in the process of teaching writing in primary school.

- most students assess themselves as a successful creator of written text, citing strategies that have contributed to this, as well as those whose application should be enhanced

- their application enables acquiring of certain knowledge, skills and attitudes, which are necessary for the successful creative writing and it contributes to their feeling of competence in this field

- that the process approach in teaching text organization enables successful creation of a text, as the important segment of literacy competence and that the process approach contributes to reaching literacy competence in its entirety.

It is known that high confidence in one's own writing capabilities - competence and selfefficacy in writing (Nikčević-Milković, 2016) additionally motivates students for creative written creation and such a feeling, through a feedback, has impact on fostering intrinsic motivation and fuels the desire for finding better strategic solutions, which in turn leads to higher achievements in the field of writing (Graham \& Harris, 2000; Nikčević-Milković, 2016; Zimmerman \& Riesemberg, 1977). Judging by their 
statements, such a competence encourages and motivates them, and it contributes to their wish and will to produce through creative writing. Thusly, students gradually become more skillful authors of texts and written expression becomes ever more adequate instrument of expression and at the same time affects voicing their thoughts and feelings, ideas and attitudes (Steele et al., 1998).

The obtained results suggest that students be continuously taught these writing strategies and that the application of these strategies in the text-creating process be more intensive. Subsequent research should focus on analyzing and assessing students' texts, in order to study the effects of applying these writing strategies.

\section{REFERENCES}

Arıc1, A. F., \& Kaldirim, A. (2015). The Effect of The Process-Based Writing Approach on Writing Success and Anxiety of Pre-Service Teachers. Anthropologist, 22(2), 318327.

Bayat, N. (2014).The Effect of The Process Writing Approach on Writing Success and Anxiety. Educational Sciences: Theory \& Practice, 14(3), 1133-1141.

Bandjur, V. \& Potkonjak, N. (1999). Metodologija pedagogije [Metodology of pedagogy]. Beograd: Savez pedagoških društava Jugoslavije.

Dayson, A. \& Freedman S. W. (2003). Writing. In J. Flood, D. Lapp, J. R. Squire \& J. M. Jensen (Eds). Handbook of research on teaching the English language arts (2 ${ }^{\text {nd }}$ ed.). Mahwah, NJ: Lawrence Erlbaum Associates.

Djordjić, S. (2014). Keativno pisanje, opšte teorije kreativnog pisanja sa primjerima. [Creatve Writing, General Theory of Creative Writing with Examples]. Niš: Filozofski fakultet.

Eco, U. (2011). Confessions of Young Novelist. Harvard, USA: Harvard University Press.

Emig, J. (1967). On teaching composition: Some hypotheses as definitions. Research in The Teaching of English, 1(2), 127-135. Retrieved from http://files.eric.ed.gov/fulltext/ED022783.pdf 06/21/2020

Emig, J. (1971). The composing processes of twelfth graders (Research Report No. 13). Urbana, IL: National Council of Teachers of English.

Englert, C. S., Stewart, S. R. \& Hiebert, E. H. (1988). Young writer's use of text structure in expository text generation. Journal of Educational Psihology, 80(2):143-151.

European Commission (2018). Proposal for a COUNCIL RECOMMENDATION on Key Competences for LifeLong Learning, Brussels. Available at https://ec.europa.eu/education/sites/education/files/swd-recommendation-keycompetences-lifelong-learning.pdf. Accessed 12 September 2018

European Commission (2018a). ANNEX to the Proposal for a Council Recommendation on Key Competences for Lifelong Learning, Brussels. Available at https://ec.europa.eu/education/sites/education/files/annex-recommendation-keycompetences-lifelong-learning.pdf. Accessed 12 September 2018 
Flower, L. \& Hayes, J. R. (1981). A cognitive process theory of writing. College Composition and Communication, 32(4), 365-387.

Gagnon, R., \& Ziarko, H. (2012). The writing of expository texts in early grades: what predicative analysis teaches us. US-China education review a, 10, 885-891.

Gains, P. \& Graham B. (2011). Making space for expressive and creative writing in African primary Schools: a two-site action research study in Kenya and South Africa. Reading and writing, 2(1):77-94.

Graham, S. \& Harris, R. K. (2000). The Role of Self-Regulation and Transcription Skills in Writing and Writing Development, Educational Psychologist, 35(1):3-12. https://doi.org/10.1207/S15326985EP3501_2

Graham, S., McKeown, D., Kiuhara, S. \& Harris, K. R. (2012). A meta-analysis of writing instruction for students in the elementary grades. Journal of Educational Psychology, 104(4), 879-896. doi:10.1037/a0029185

Graham, S. \& Perin, D. (2007). A meta-analysis of writing instruction for adolescent students. Journal of Educational Psychology, 99(3), 445-476. doi:10.1037/00220663.99.3.445

Graham, S., \& Sandmel, K. (2011). The process writing approach: A meta-analysis. Journal of Educational Research, 104(6), 396-407. doi:10.1080/00220671.2010.488703

Graves, D. H. (1983). Writing: Teachers and children at work. Portsmouth, NH: Heinemann.

Graves, D. H. (1994). A fresh look at writing. Portsmouth: Heinemann.

Grosman, M. (2010). U obranu čitanja, čitatelj i književnost u 21. stoljeću [In defense of reading, reader and literature in the 21st century]. Zagreb, Croatia: Algoritam, Traduki.

Hall, A. H. \& Axelrod, Y. (2014). "I am kind of a good writer and kind of not": examining students' writing attitudes. Journal of research in education, 24(2).

Halmi, A. (2013). Temelji kvantitativne analize u društvenim znanostima. [Foundations of Quantitative Analiysis in the Social Sciences]. Zagreb: Alinea.

Hayes, J. R. \& Flower, L. (1980). Identifying the organization of written processes. In L. W. Gregg, \& E. R. Steinberg (Eds.). Cognitive processes in writing (pp. 3-30). Hillsdale, NJ: Lawrence Erlbaum Associates.

Hayes, J. R. \& Flower, L. (1986). Writing research and the writer. American Psychologist, 41(10), 1106-1113. doi:10.1037/0003-066X.41.10.1106

Ispitni centar Crne Gore [Examination Center of Monetnegro] (2017). PISA 2015. u Crnoj Gori, rezultati [PISA 2015 in Montenegro, Results]. Podgorica: Ispitni centar Crne Gore.

Jay, T. B. (2003). The Psychology of Language. New Jersey: Pearson Educaton. 
Murray, D. M. (1968). A writer teaches writing: A practical method of teaching composition. New York, NY: Houghton Mifflin.

Murray, D. M. (1972). Teaching writing as a process not product. The Leaflet, November, 11-14.

Nikolić, M. (2009). Metodika nastave srpskog jezika i književnosti, 5. dopunjeno izdanje [Methodology of teaching Serbian language and literature, $5^{\text {th }}$ revised edition]. Beograd, Serbia: Zavod za udžbenike.

Nikčević-Milković, A. (2016). Psihologija pisanja - određenje područja, motivacija, samoregulacija, poučavanje, metode istražvanja, esejsko ispitivanje. Napredak: časopis za pedagogijsku teoriju i praksu [Psychology of Writing - defining areas, motivation, self-regulation, teaching, researching methods, essay examination. Progress: Journal of Pedagogical Theory and Practice], 157(1-2):124-144. Available at https://hrcak.srce.hr/177227. Accessed 22 Jun 2020.

Po, E. A. (1964). Filozofija kompozicije. In Odabrana dela [Philosophy of the Composition. In Chosen Work]. Beograd: Nolit.

Popović, D. (2013). Put stvaraoca ili kako stvarati tekst. In D. Popović (Ed.) Kako učenicima pomoći da uspješno stvaraju usmene i pisane, umjetničke $i$ neumjetničke tekstove - prvi koraci. (pp. 10-22). [The Creator`s Path or How to Create a Text, How to help students to successfully produce oral and written, artistic and non-artistic texts, first results]. Podgorica: Zavod za školstvo.

Popović, D. \& Novović, T. (2016). Teaching Writing Skills - How To Start Writing a Text. Croatian Journal of Education, Vol. 18; No.4/2016, 1235-1273.

Rosandić, D. (2002). Od slova do teksta i metateksta [From a Letter to a Text and Metatext]. Zagreb, Croatia: Profil.

Sezgin, D. (2018). The Relation between the Awareness Level of Writing Strategies and Writing Self-Efficacy. International Education Studies, 11(5):59 doi: 10.5539/ies.v11n5p59

Steele, L. Jeanie, Kurtis S. Meredith and Charles Temple (1998). Radionica za pisanje: Od samoizražavanja do izražavanja stajališta, vodič pripremljen za primjenu Projekta Čitanje i pisanje za kritičko mišljenje [Writing Workshop: From self-expression to the expression of views, a guide prepared for the implementation of the Project Reading and writing for critical thinking]. Zagreb: Otvoreno društvo.

Strunk, W. Jr. \& White, E. B. (2003). The Elements of Style ( $4^{\text {rd }}$ ed.). New York: Macmillan Publishing Co.

Zavod za školstvo, Ispitni centar Crne Gore [Bureau for Education Services, Examination Center of Monetnegro] (2013). PISA 2012 - Crna Gora, preliminarni izvještaj [PISA 2012 - A Preliminary Report]. Podgorica: Ispitni centar Crne Gore.

Zimmerman, B. J. \& Risemberg, R. (1997). Becoming a Self-Regulated Writer - A Social Cognitive Perspective. Contemporary Educational Psychology, 22(1), 73-101. 